\title{
ANALISIS PROBABILISTIK BAHAYA GEMPA PADA BENDUNGAN WADASLINTANG
}

\author{
Rahma Kusuma Dewi ${ }^{1)}$, Yusep Muslih Purwana ${ }^{2}$, dan Raden Harya Dananjaya ${ }^{2)}$ \\ 1) Mahasiswa Fakultas Teknik, Prodi Teknik Sipil, Universitas Sebelas Maret \\ 2) Pengajar Fakultas Teknik, Prodi Teknik Sipil, Universitas Sebelas Maret \\ J1. Ir. Sutami 36A, Surakarta 57126; Telp.0271-634524.Email: rahmakadewi97@gmail.com
}

\begin{abstract}
Indonesia is one of the countries with a high seismic intensity level, seen from its location close to gempa sources including subduction zones, active faults, and pacific fire (volcanoes) scattered throughout the area. Among several islands in Indonesia, Java Island is one of the islands with high seismic activity. The island with the most population, as the center of government and industrial activities makes Java has a high level of risk of damage to buildings and infrastructure. One of the buildings that has a bigh level of risk is a dam. This study will evaluate the gempa hazard in one of Indonesia's large dams is Wadaslintang Dam. The dam is located on the border of 3 major districts, Kebumen, Purworejo and Wonosobo. This dam was constructed in 1982 until 1987, with height of $116 \mathrm{~m}$. Considering that the age of the dam is more than 30 tahun, and the potential for gempas is quite high, it is necessary to evaluate the gempa risk in the Wadaslintang Dam. This analysis uses the Probabilistic Seismic Hazard Analysis (PSHA) method using R-Crisis 2018 software. The results of the PSHA analysis show the peak ground acceleration values in the review location with a return period of 500, 2,500 and 10,000 tahun is $0.22 \mathrm{~g} ; 0.35 \mathrm{~g}$ and $0.52 \mathrm{~g}$ respectively. The results of the disaggregation process showed the magnitude and distance of the gempa that most influence to the location are 6.87 - 7.13 Mw and the distance of 0-33 km. Ground motion search results, it was found that the Irpinia Gempa, Italy (1980) which has the same criteria as the review location of according to the disaggregation results.
\end{abstract}

Keywords: Earthquake, Wadaslintang Dam, PSHA, Disaggregation, Ground Motion.

\begin{abstract}
Abstrak
Indonesia merupakan salah satu negara dengan dengan tingkat intensitas kegempaan yang cukup tinggi, terlihat dari lokasinya yang berdekatan dengan sumber-sumber gempa diantaranya, zona subduksi, sesar (fault) yang aktif, dan cinicin api pasifik (gunung berapi) yang tersebar di sepanjang negara kepulauan ini. Diantara beberapa pulau di Indonesia, Pulau Jawa menjadi salah satu pulau dengan aktivitas seismik yang tinggi. Pulau dengan jumlah penduduk paling banyak, sebagai pusat pemerintahan dan kegiatan industri menjadikan Jawa mempunyai tingkat resiko kerusakan bangunan dan infrastruktur yang cukup tinggi. Salah satu bangunan yang mempunyai tingkat resiko tinggi adalah bendungan urugan. Penelitian ini akan mengevaluasi bahaya gempa pada salah satu bendungan besar Indonesia yaitu Bendungan Wadaslintang. Bendungan ini terletak di perbatasan 3 kabupaten besar yaitu Kabupaten Kebumen, Purworejo dan Wonosobo. Bendungan ini dibangun pada tahun 1982 sampai 1987, dengan tinggi 116 m. Mengingat usia bendungan yang mencapai 31 tahun serta potensi gempa yang cukup tinggi, maka perlu adanya evaluasi terbaru mengenagi resiko gempa di Bendungan Wadaslintang. Analisis ini menggunakan metode Probabilistic Seismic Hazard Analysis (PSHA) dengan bantuan software R-Crisis 2018. Hasil analisis PSHA menunujukkan nilai percepatan tanah maksimum di lokasi tinjuan dengan periode ulang 500, 2.500, dan 10.000 tahun sebesar 0,22 g; 0,35 g dan 0,52 g. Hasil dari proses deagregasi menunjukkan besaran dan jarak gempa yang paling berpengaruh terhadap Bendungan Wadaslintang sebesar 6,87 - 7,13 Mw dan jarak 0-33 km. Hasil pencarian ground motion, didapatkan bahwa Gempa Irpinia, Italia (1980) mempunyai kriteria yang sama dengan lokasi tinjuan sesuai hasil deagregasi.
\end{abstract}

Kata kunci: Gempa Bumi, Bendungan Wadaslintang, PSHA, Deagegasi, Ground Motion.

\section{PENDAHULUAN}

Indonesia merupakan salah satu negara dengan dengan tingkat intensitas kegempaan tektonik dan vulkanisme yang cukup tinggi. Diantara beberapa pulau di Indonesia, Pulau Jawa menjadi salah satu pulau dengan aktivitas seismik yang tinggi dengan kemunculan patahan serta pertemuan lempeng Eurasia dan Indo-Autralia yang membentuk zona subduksi sepanjang garis terluar pantai selatan pulau ini. Pulau dengan jumlah penduduk paling banyak, sebagai pusat pemerintahan dan kegiatan industri menjadikan Jawa mempunyai tingkat resiko kerusakan bangunan dan infrastruktur yang cukup tinggi. Salah satu cara untuk meminimalisir kerugian yang terjadi akibat gempa adalah mendeteksi bahaya gempa yang terjadi pada suatu bangunan atau infrastuktur. Salah satu bangunan yang mempunyai tingkat resiko tinggi adalah bendungan urugan.

Penelitian ini akan menganalisis bahaya gempa pada salah satu bendungan besar Indonesia yaitu Bendungan Wadaslintang. Bendungan ini terletak di perbatasan 3 kabupaten besar yaitu Kabupaten Kebumen, Purworejo dan Wonosobo. Bendungan ini dibangun pada tahun 1982 sampai 1987, dengan tinggi 116 m. Tujuan penelitian ini adalah mengkaji ulang bahaya gempa pada Bendungan Wadaslintang dari kemunculan sumber-sumber gempa baru yaitu sesar (patahan). Kemunculan sesar baru berdasarkan Peta Gempa 2017 yang berada di radius 300 km dari 
titik Bendungan Wadaslintang antara lain sesar ajibarang, sesar semarang, sesar opak, sesar merapi-merbabu, sesar pekalongan dan sesar brebes.

Analisis ini menggunakan metode Probabilistic Seismic Hazard Analysis (PSHA) dengan bantuan software R-Crisis 2018. Metode PSHA adalah metode analisis bahaya gempa probabilistik dengan memperhitungkan dan menggabungkan ketidakpastian dari magnitude, lokasi, dan waktu kejadian gempa. Hasil PSHA merupakan percepatan gempa maksimum yang mungkin terjadi pada periode ulang tertentu. Disisi lain, kejadian gempa yang mungkin akan datang tidak dapat terlihat jelas dalam PSHA. Dengan kondisi seperti ini PSHA menjadi kurang lengkap memberikan informasi tentang parameter gempa yaitu magnitude $(M)$ dan jarak $(R)$ yang dominan dalam desain gempa. Untuk melengkapi metode PSHA maka diperlukan deagregasi terhadap setiap sumber gempa yang dimodelkan.

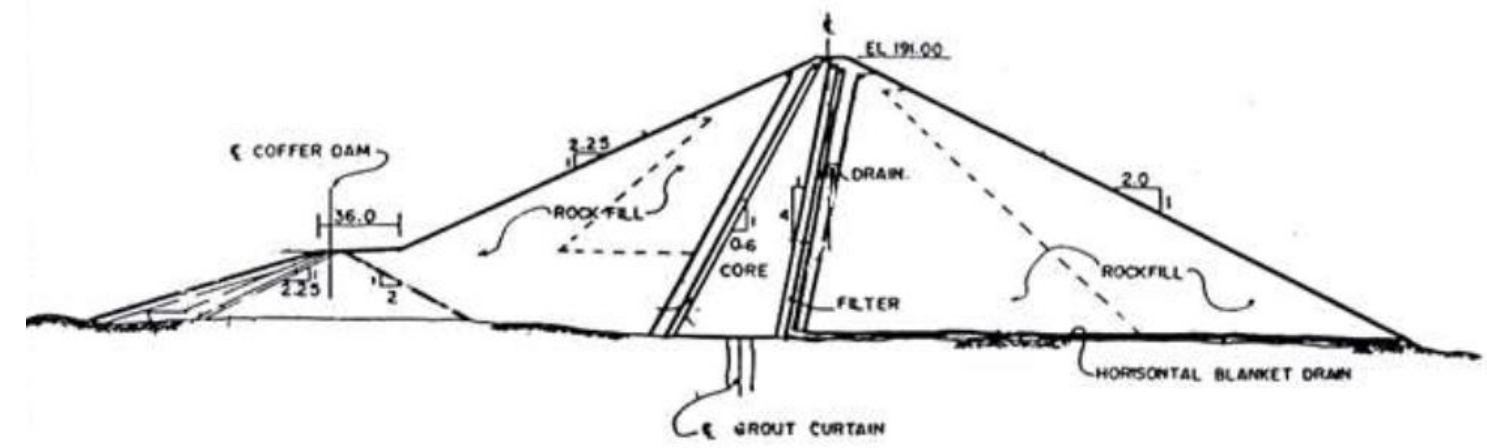

Gambar 1 Potongan Melintang Bendungan Wadaslintang

\section{LANDASAN TEORI}

Gempa bumi adalah getaran yang terjadi di permukaan bumi akibat adanya pelepasan energi yang dihasilkan oleh lempeng tektonik yang saling bergerak. Mekanisme konveksi suhu pada bagian mantel bumi menjadi penyebab terjadinya pergerakan antar plat bumi. Pergerakan plat bumi yang saling mendekat tersebut yang menyebabkan terjadinya gempa bumi. Semakin besar tekanan yang dihasilkan antara kedua lempeng tektonik hingga mencapai batas maksimum, dapat mengakibatkan lempeng yang satu menghujam dibawah lempeng lain yang membentuk bidang batas atau bidang kontak dengan kemiringan (dips) tertentu yang disebut dengan zona subduksi, sebagai salah satu sumber terjadinya gempa bumi.

\section{Probabilistic Seismic Hazard Analysis (PSHA)}

Metode Probabilistic seismic hazard analysis (PSHA) pertama kali dikembangkan oleh Cornel (1968), kemudian dilanjutkan oleh Merz dan Cornel (1973) dan penelitian lebih lanjut dikembangkan oleh Mc. Guire (1976). Analisis ini bertujuan untuk menentukan probabilitas terlampauinya nilai percepatan gempa pada suatu periode ulang tertentu. Teori mengasumsikan bahwa gempa dengan magnitude (M) dan distance (R) sebagai suatu variable acak. Metode PSHA terdiri dari 4 langkah utama yang seperti yang dijelaskan oleh Reiter L. (1990), seperti ditunjukkan pada Gambar 2. Langkah pertama yaitu identifikasi sumber-sumber gempa. Kedua, karakterisasi parameter seismic gempa. Ketiga, pemilihan fungsi atenuasi. Keempat, perhitungan bahaya gempa.

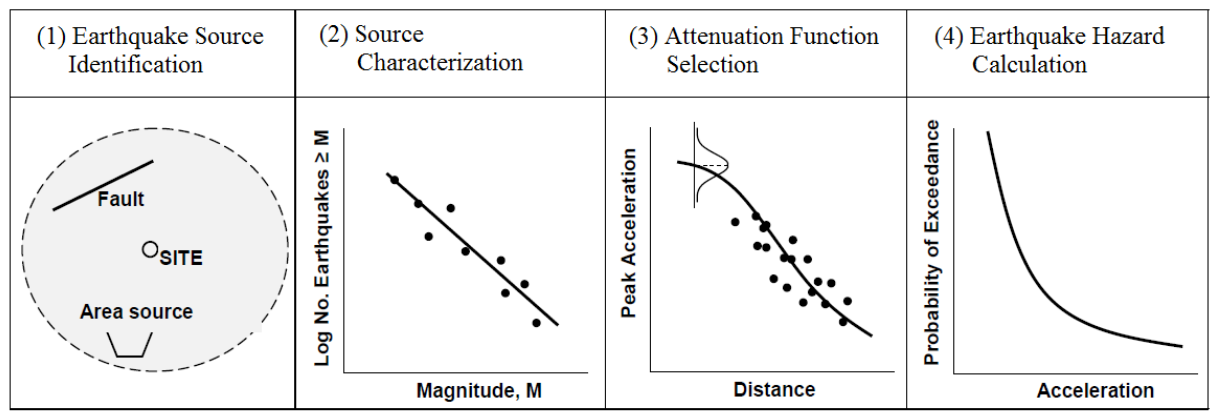

Gambar 2 Langkah-langkah metode PSHA

Persamaan umum PSHA dapat dilihat pada Persamaan 1 berikut

$\boldsymbol{P} \boldsymbol{x}=\int r \int m P[I \geq i \mid m$ dan $r] . f_{M}(m) \cdot f_{r}(r) d m d r$. 
dengan:
$f_{M}$
$f_{r}$
$=$ fungsi kepadatan magnitude
$P[I \geq i \mid m$ dan $r]$
= fungsi kepadatan jarak hiposenter
magnitude (M) dan jarak hiposenter (R).

Pemodelan Sumber Gempa

Pada analisis resiko gempa (Seismic hazard analysis), pemodelan sumber gempa dibutuhkan untuk mengetahui tingkat resiko gempa tiap area sumber gempa yang dimodelkan. Analisis ini sumber gempa dimodelkan menjadi 3 model, yaitu sumber gempa patahan, sumber gempa subduksi, dan sumber gempa background.

1. Sumber gempa patahan, yaitu gempa yang terjadi karena patahan yang telah teridentifikasi parameternya seperti mekanisme patahan, nilai slip rate, kemiringan (dip), panjang dan lokasi patahan.

2. Sumber gempa subduksi, yaitu gempa yang terjadi karena pertemuan lempeng tektonik dengan salah satu lempeng menghujam naik mendorong ke bawah lempeng yang satunya. Sumber gempa ini dimodelkan dengan kedalaman 0-50 km, sedangkan untuk kedalaman lebih dari $50 \mathrm{~km}$ dimodelkan menjadi sumber gempa background.

3. Sumber gempa background ini sebenarnya sebenarnya belum diketahui jelas berasal dari patahan atau subduksi. Pada pemodelan sumber gempa background biasanya dibagi menjadi 2 berdasarkan kedalaman yaitu shallow background dengan kedalaman dibatasi hingga $50 \mathrm{~km}$ dimana semua gempa di daerah Megathrust dihilangkan dan deep background dengan kedalaman 50-300 km

\section{Parameter Seismik}

Pada analisis resiko gempa (Seismic hazard analysis) membutuhkan beberapa parameter seismik dari setiap pemodelan area sumber gempa. Perhitungan parameter seismik menggunakan persamaan Gutenberg \& Richter (1994) untuk mendapatakan nilai activity rate $(\lambda)$ dan ab-value. Persamaan empiris dari Gutenberg \& Richter (1944) dapat dilihat Persamaan 2 berikut.

$\log (\lambda)=a-b \cdot M$

dimana a merupakan nilai konstanta dari setiap are asumber gempa berdasarkan waktu pengamatan dan tingkat intensitas gempa, sedangkan b merupakan nilai konstanta tiap area yang merepresentasikan kemiringan grafik, dan M merupakan nilai magnitude.

\section{Fungsi Atenuasi}

Salah satu unsur penting dalam PSHA adalah pemilihan fungsi atenuasi. Fungsi atenuasi juga sering dikenal sebagai ground motion prediction relationship (GMPE). Pada wilayah Indonesia, dikarenakan ketidaklengkapannya data rekaman gempa (ground motion) maka fungsi atenuasi yang spesifik di wilayah Indonesia belum tersedia. Pemilihan fungsi atenuasi di Indonesia didasarkan pada kesamaan kondisis geologi dan tektonik dari wilayah tempat fungsi atenuasi tersebut dibuat. Persamaan GMPE yang digunakan saat ini di Indonesia adalah sebagai berikut.

1. Shallow crustal gempa, untuk pemodelan sumber gempa dengan kedalaman 0-50 km.
a. Boore-Atkinson NGA
b. Campbell-Bozorgnia NGA
c. Chiou-Youngs NGA

2. Subduction interface (Megathrust), untuk sumber gempa subduksi.
a. BCHydro
b. Atkinson-Boore $B C$ rock and global source subduction
c. Zhao et al, 2006

3. Benioff (deep background) source, untuk pemodelan sumber gempa dengan kedalaman 51-300 km.
a. $\mathrm{AB}$ intraslab seismicity Cascadia region BC-rock condition
b. Geometrix slab seismicity rock, 1997
c. AB 2003 intraslab seismicity worldwide data region BC-rock condition

\section{Logic Tree}

Logic Tree adalah suatu sistem kerja untuk mengatasi ketidakpastian parameter dalam proses analisis resiko gempa dengan metode PSHA. Pendekatan logic tree memungkinkan penggunaan beberapa alternatif metode atau model 
dalam analisis dimana tiap model yang digunakan untuk suatu parameter akan dikalikan dengan suatu faktor bobot yang merepresentasikan keakuratan relatif suatu model lainnya (Irsyam, 2010). Jumlah faktor bobot dari semua alternatif metode untuk parameter yang sama harus sama dengan 1 (satu).

\section{METODE PENELITIAN}

Metode penelitian yang digunakan adalah deskriptif kuantitatif. Analisis bahaya gempa dengan metode probabilistik dengan memanfaatkan beberapa data sekunder yang meliputi:

1. Katalog rekam gempa dari tahun 1900 - 2018, dari 3 sumber katalog internasional yaitu United States Geological Survey (USGS), Advanced National Seismic System (ANSS) dan International Seismological Centre (ISC). Kriteria dalam pencarian katalog gempa tersebut ialah sebagai berikut:
a. Longitude
$=109$ 48'1,08' BT
b. Latitude
$=736$ '5,76" LS
c. Radius
$=500 \mathrm{~km}$
d. Magnitude
$=4.0-9.0$
e. Depth
$=0-300 \mathrm{~km}$

2. Peta digital Kabupaten Wonosobo, Purworejo dan Kebumen, produksi Badan Informasi Geospasial, termasuk di dalamnya peta administrasi. Lokasi Bendungan Wadaslintang ditunjukkan pada Gambar 3 berikut ini.

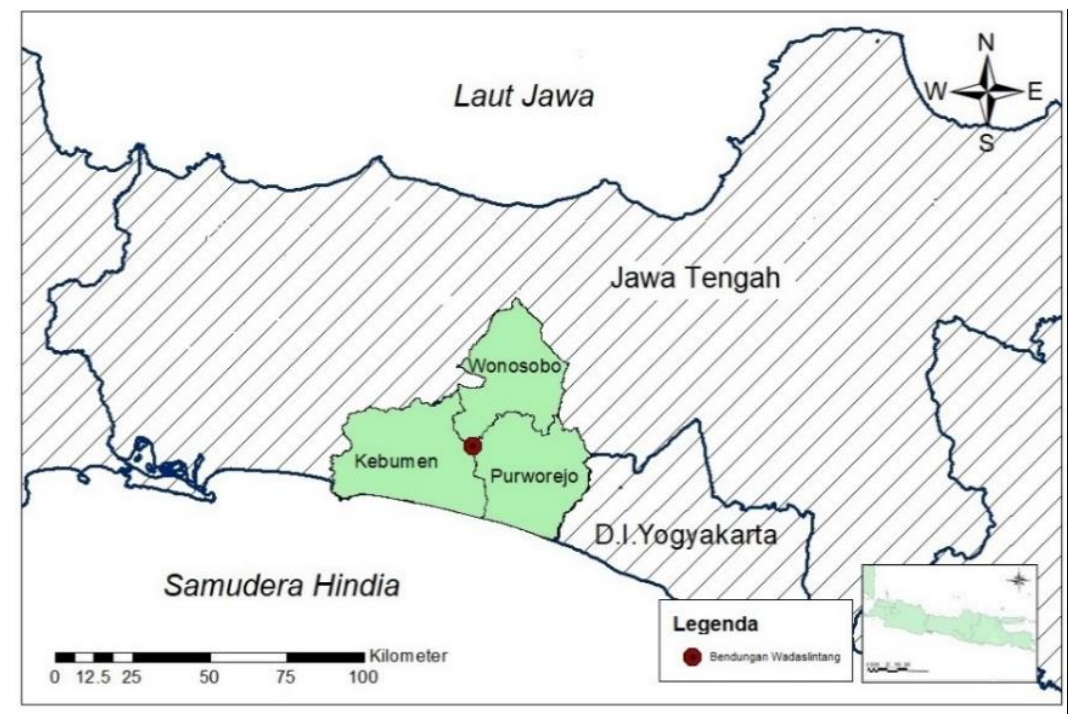

Gambar 3 Lokasi Bendungan Wadaslintang

Data di atas kemudian diolah dengan menggunakan bebrapa perangkat digital yang terdiri dari:

1. Microsoft Office Excel, digunakan untuk penyeragaman speriode magnitude gempa yang menjadi input file pada proses declustering. Selain itu digunakan juga pada tahapan analisis kelengkapan data gempa.

2. Z-map 6.0, program berbasis Matlab digunakan pada tahapan declustering data rekam gempa.

3. ArcMap versi 10.2, digunakan untuk membuat area sources pada pemodelan sumber gempa.

4. R-Crisis versi 18.3, digunakan untuk analisis bahaya gempa dengan metode PSHA, dan proses deagregasi.

\section{HASIL DAN PEMBAHASAN}

\section{Hasil Pengumpulan Data Rekam Gempa}

Rekam data gempa atau data kejadian gempa sebelumnya merupakan sumber utama dalam proses analisis PSHA. Pada studi ini menggunakan 3 sumber katalog gempa antara lain International Seismological Centre (ISC) catalog [11], United States Geological Survey (USGS) dan Advanced National Seismic System (ANSS). Hasil rekapitulasi pengumpulan data gempa disajikan pada Tabel 1 berikut. 


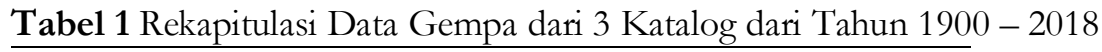

\begin{tabular}{ccc}
\hline No & Katalog Gempa & Jumlah data gempa \\
\hline 1. & ISC & 7778 data \\
\hline 2. & USGS & 3314 data \\
\hline 3. & ANSS & 3225 data \\
\hline & Total & 14317 data
\end{tabular}

Untuk lebih jelasnya, hasil pengumpulan data dapat dilihat pada Gambar 4 di bawah ini.

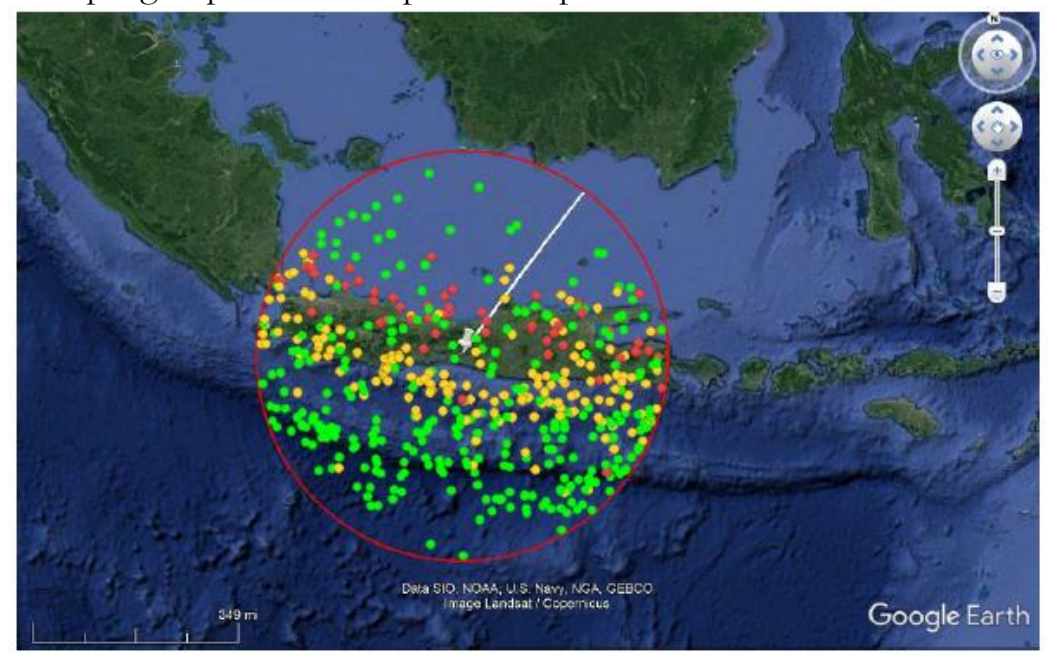

Gambar 4 Data kejadian gempa dari tahun 1990 - 2018

\section{Analisis Kelengkapan Data Gempa}

Data dari semua katalog berisi baik gempa susulan (foreshock dan aftershock) dan gempa utama (mainshock), hanya gempa utama yang digunakan dalam perhtiungan PSHA. Metode Gardner dan Knopoff (1974) digunakan untuk memisahkan data gempa utama dari gempa susulan (declustering). Untuk melakukan proses declustering, program ZMAP dikembangkan oleh Wiemer (2001) digunakan dalam penelitian ini.

Data hasil decluster selannjutnya dilakukan analisis kelengkapan data gempa. Ketidaklengkapan data dapat menyebabkan parameter seismik overestimated atau underestimated. Metode Stepp (1973) digunakan untuk memperoleh kelengkapan data di mana data gempa dibagi menjadi beberapa rentang magnitudo. Akhirnya, data untuk setiap rentang besarnya dianalisis oleh banyak peristiwa gempa, frekuensi kejadian gempa, dan standar deviasi. Hasil kelengkapan data disajikan pada Gambar 5.

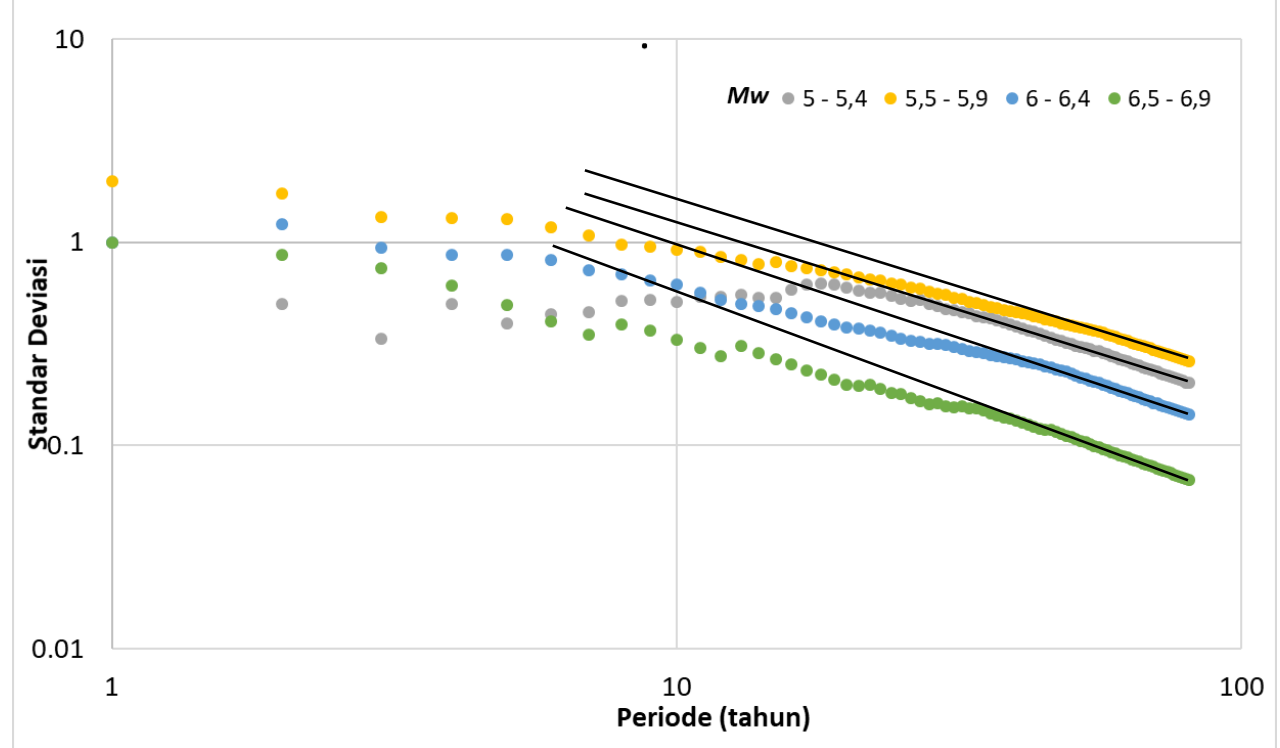

Gambar 5 Hasil analisis kelengkapan data

Dilihat dari pengamatan visual dari garfik kelengkapan data diatas menunjukkan range tahun yang memiliki data gempa yang lengkap ditunukkan pada Tabel 2 berikut. 
Tabel 2 Interval Kelengkapan Data Gempa

\begin{tabular}{cc}
\hline Magnitude Range & Completeness Interval (Tahun) \\
\hline $5,0-5,4$ & $2002-2018$ \\
\hline $5,5-5,9$ & $1992-2018$ \\
\hline $6,0-6,4$ & $1976-2018$ \\
\hline $6,5-7,0$ & $1973-2018$ \\
\hline
\end{tabular}

\section{Hasil Pemodelan Sumber Gempa}

Dalam penelitian ini sumber gempa dibuat dengan memodelkan daerah berdasarkan 3 kedalaman, termasuk 0-50 km, 50-175 km, dan 175-300 km. Hasil pemodelan sumber gempa dapat dilihat pada Gambar. 6 berikut ini.

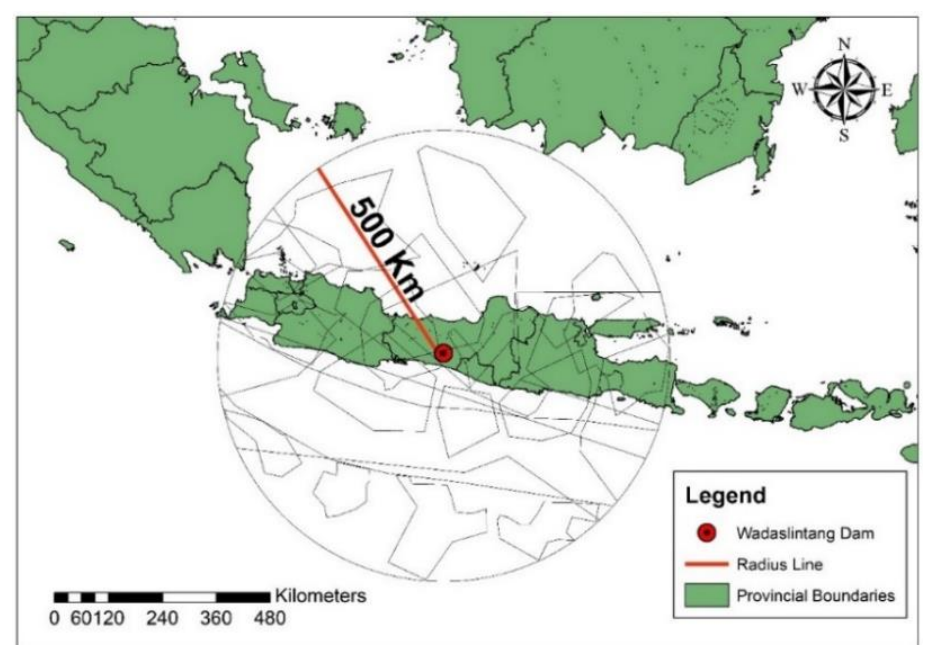

Gambar 6 Hasil pemodelan sumber gempa

\section{Peta Seismic Hazard}

R-CRISIS 18.3 digunakan untuk menghitung analisis bahaya gempa menggunakan metode probabilistik. Nilai peak ground acceleration (PGA) dilakukan pada 3 Kabupaten yaitu Kebumen, Wonosobo dan Purworejo. Gambar 7 hingga Gambar 9 menunjukkan hasil peta seismic hazard map untuk periode ulang 500, 2500, 10000 tahun berikut ini.

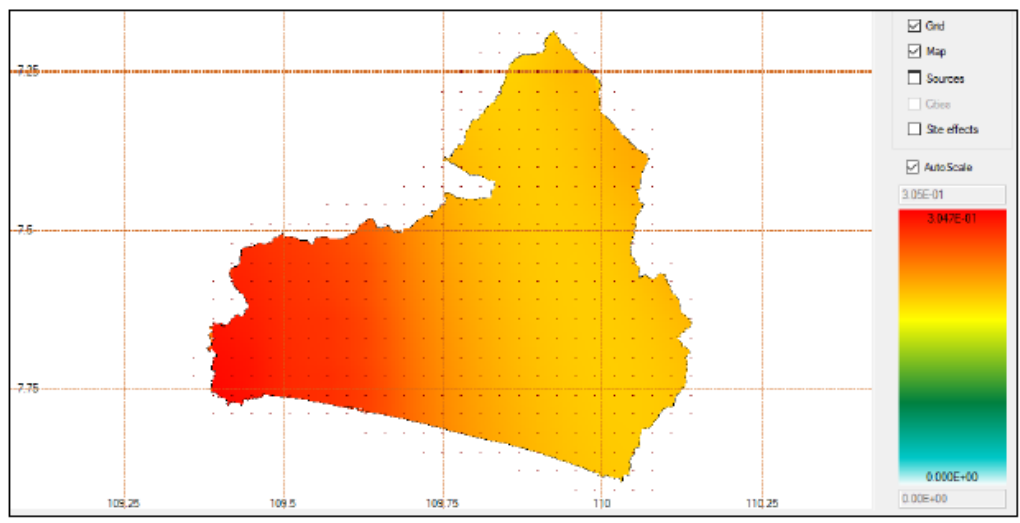

Gambar 7 Seismic hazard map pada periode ulang 500 tahun 


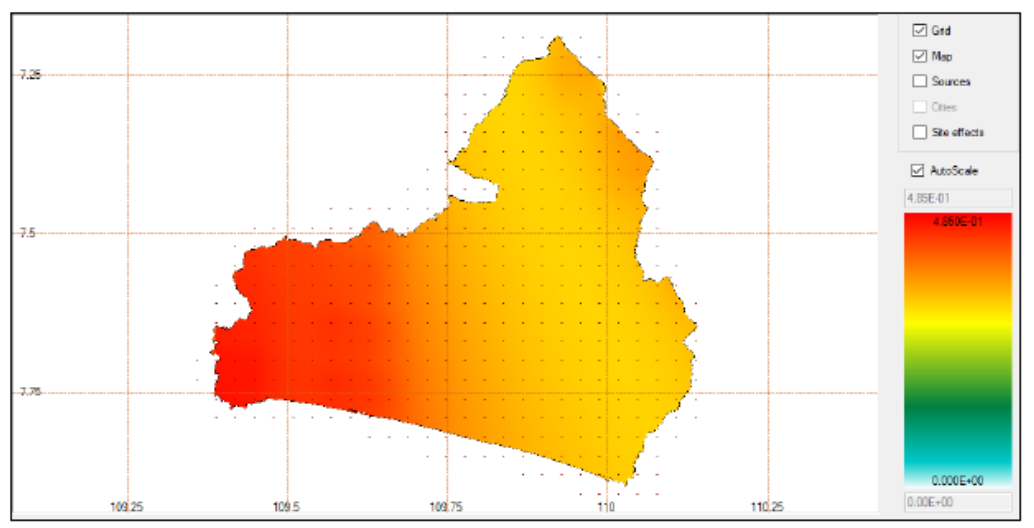

Gambar 8 Seismic hazard map pada periode ulang 2500 tahun

Gambar 7 hingga 8 menunujukkan hasil hazard map dari analisis PSHA untuk 3 kabupaten yang berbatasan langung dengan lokasi bendungan. Perbedaan warna pada gambar diatas menunjukkan tingkat intensitas gempa, dimana warna merah memiliki intensitas yang paling besar. Nilai intensitas gempa untuk lokasi titik bendungan dengan periode ulang 500 tahun adalah $0,22 \mathrm{~g}$. Nilai intensitas gempa untuk lokasi titik bendungan dengan periode ulang 2500 tahun adalah $0,35 \mathrm{~g}$.

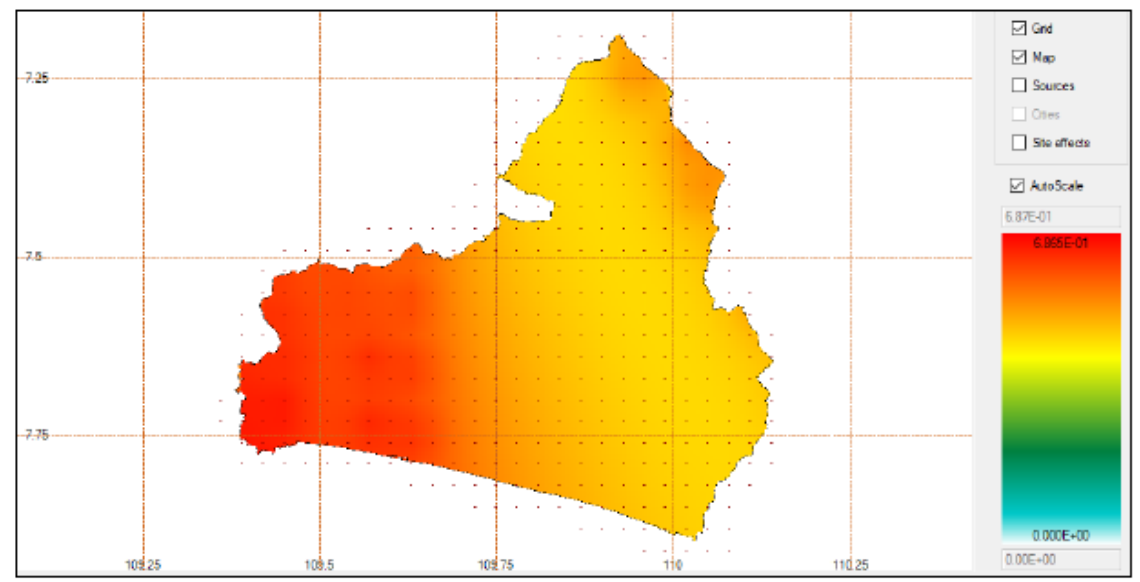

Gambar 9 Seismic hazard map pada periode ulang 10.000 tahun

Gambar 9 menunujukkan hasil hazard map dari analisis PSHA untuk 3 kabupaten yang berbatasan langung dengan lokasi bendungan. Perbedaan warna pada gambar diatas menunjukkan tingkat intensitas gempa, dimana warna merah memiliki intensitas yang paling besar. Nilai intensitas gempa untuk lokasi titik bendungan dengan periode ulang 10.000 tahun adalah 0,52g. Berdasarkan hasil analisis PSHA untuk Bendungan Wadaslintang dapat disajikan dalam bentuk grafik hubungan nilai peak ground acceleration (PGA) terhadap waktu kejadian gempa (periode) seperti pada Gambar 10 berikut. 


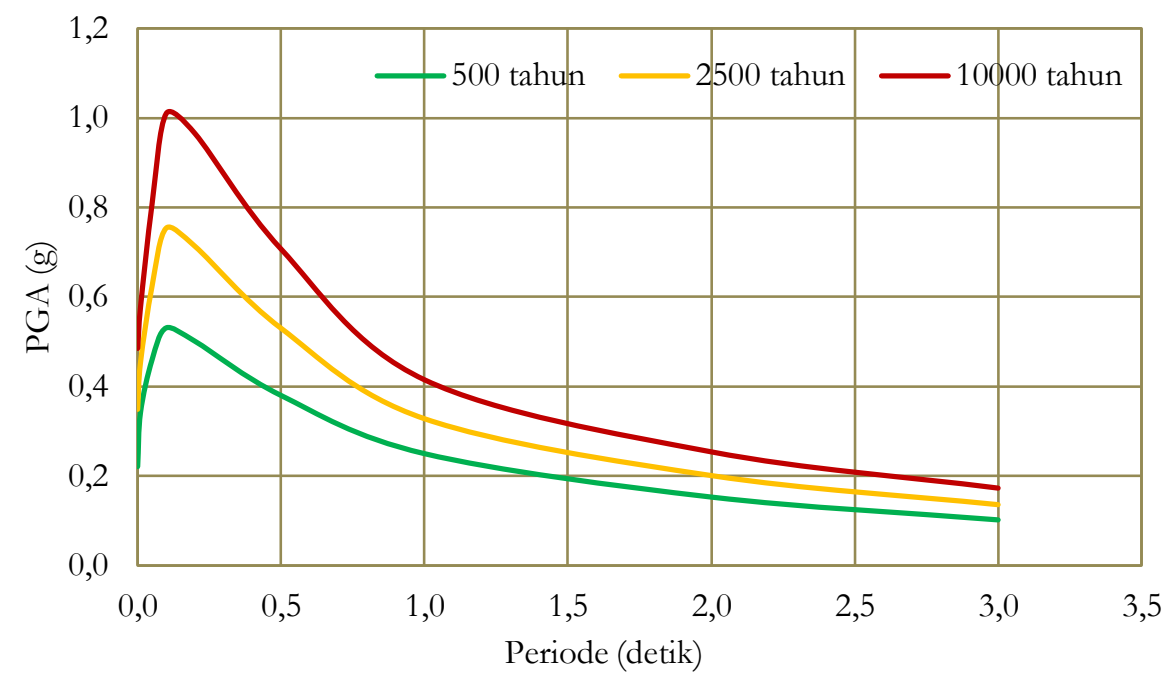

Gambar 10 Hubungan nilai PGA terhadap waktu kejadian gempa (periode) untuk 3 periode ulang gempa

Gambar 10 menunjukkan bahwa nilai percepatan gempa maksiumum (PGA) akan semakin besar berbanding lurus dengan semakin besarnya periode ulang gempa periode ulang 500 tahun mempunyai nilai PGA terkecil sebesar $0,22 \mathrm{~g}$ dan periode ulang 10.000 tahun mempunyai nilai PGA terbesar yaitu $0,52 \mathrm{~g}$.

\section{Seismic Hazard Curve}

Penelitian ini memperhitungkan 3 periode ulang yaitu 500 tahun, 2500 tahun, dan 10000 tahun. Hal penting yang perlu diketahui untuk mendapatkan nilai percepatan tanah maksimum periode ulang tertentu adalah nilai exceedance probability. Nilai Exceedance probability sangat berkaitan dengan waktu layan struktur bangunan dan periode ulang. Hasil seismic hazard curve dari Bendungan Wadaslintang dapat dilihat pada Gambar 11 berikut.

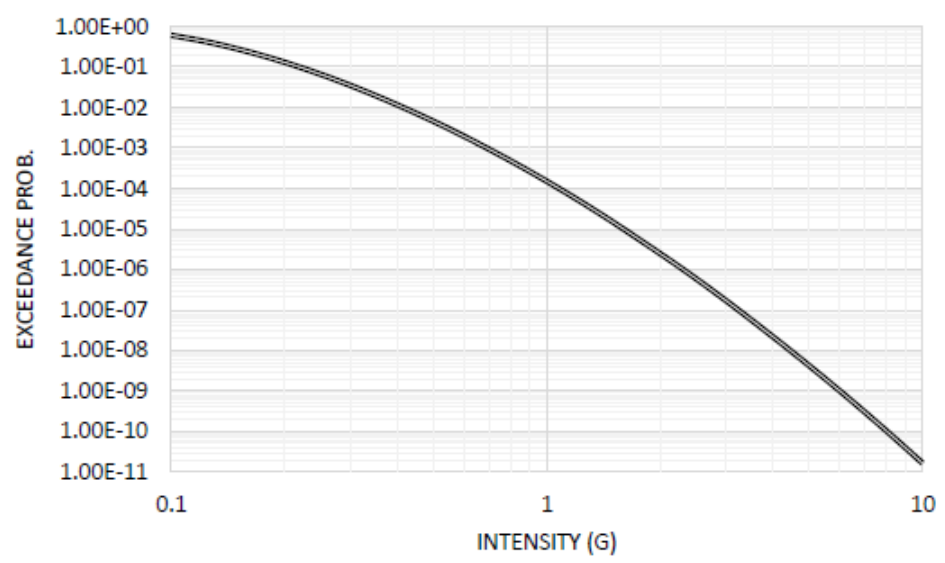

Gambar 11 Seismic hazard curves untuk Bendungan Wadaslintang

Gambar 11 menunjukkan bahwa dengan semakin besar nilai intensitas gempa (PGA) akan diikuti dengan penurunan nilai probabilitas kemungkinan kejadian gempa tersebut. Rekapitulasi nilai exceedance probability dan percepatan gempa maksimum (PGA) dapat dilihat pada Tabel 3 berikut.

Tabel 3 Rekapitulasi Nilai Exceedance Probability dan Percepatan Gempa Maksimum (PGA)

\begin{tabular}{cccc}
\hline \multirow{2}{*}{$\begin{array}{c}\text { Periode Ulang } \\
\text { (tahun) }\end{array}$} & $\begin{array}{c}\text { Exceedance } \\
\text { Probability }\end{array}$ & $\begin{array}{c}\text { Hasil Pusgen } \\
\mathbf{2 0 1 7}\end{array}$ & $\begin{array}{c}\text { Hasil } \\
\text { Analisis }\end{array}$ \\
\hline 500 & 0,0952 & $0,2-0,25$ & 0,22 \\
\hline 2500 & 0,0198 & $0,3-0,4$ & 0,35 \\
\hline 10000 & 0,00499 & $0,5-0,6$ & 0,52 \\
\hline
\end{tabular}




\section{Deagregasi}

Hasil PSHA merupakan nilai percepatan gempa maksimum yang mungkin terjadi pada suatu periode ulang tertentu. Disisi lain, kejadian gempa yang mungkin akan datang tidak dapat terlihat jelas dalam PSHA. Dengan kondisi seperti ini PSHA menjadi kurang lengkap memberikan informasi tentang parameter gempa yaitu magnitude (M) dan jarak (R) yang dominan dalam desain gempa. Untuk melengkapi metode PSHA maka diperlukan deagregasi terhadap setiap sumber gempa yang dimodelkan. Deaggregasi adalah salah satu proses analisis R-Crisis. Hasil dari proses ini adalah besarnya dan jarak mewakili kontribusi yang paling berpengaruh terhadap lokasi. Hasil deagregasi untuk 3 periode ulang dapat dilihat pada Gambar. 12 hingga 14 berikut ini.

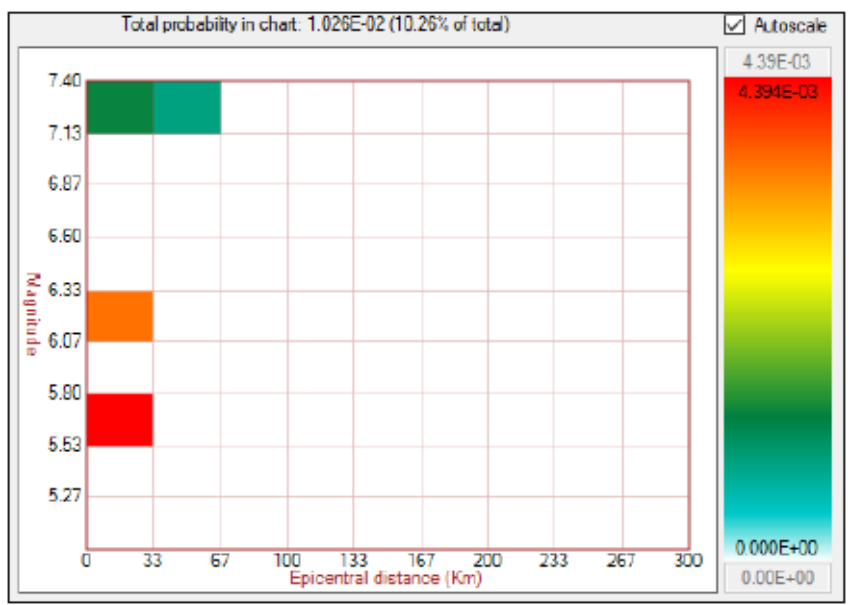

Gambar 12 Hasil deagregasi untuk periode ulang gempa 500 tahun

Gambar 12 menunjukkan hasil deagregasi untuk periode ulang gempa 500 tahun. Pembacaan hasil degregasi dilihat pada persebaran warna, dimana warna merah mempunyai kemungkinan kejadian paling besar, Hasil deagregasi bendugan untuk gempa kala ulang 500 tahun adalah magnitude dengan range 5,53 hingga 5,80 Mw dan jarak 0 hingga $33 \mathrm{~km}$.

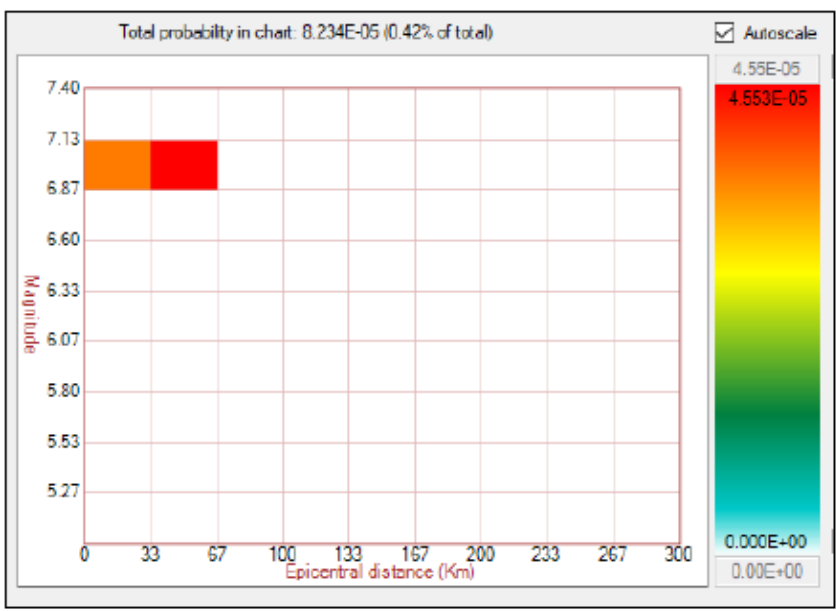

Gambar 13 Hasil deagregasi untuk periode ulang gempa 2500 tahun 


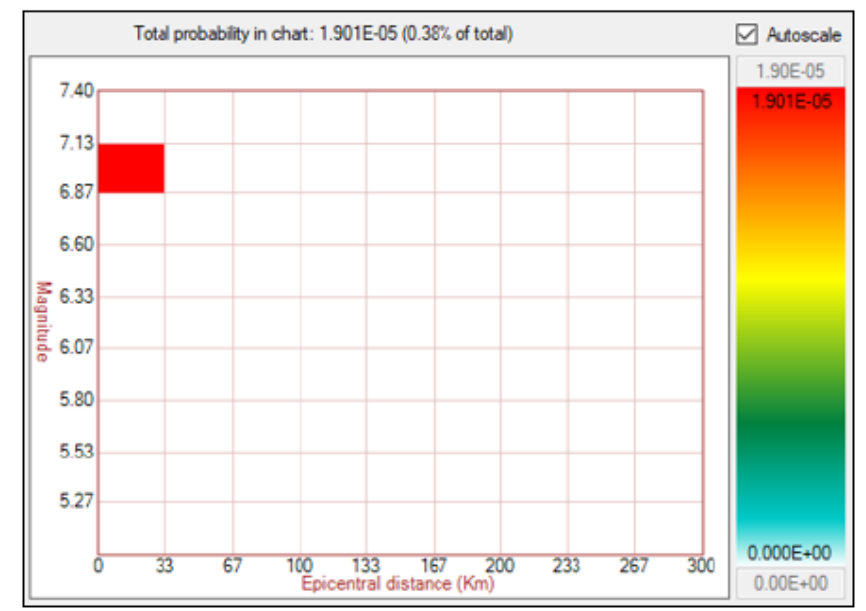

Gambar 14 Hasil deagregasi untuk periode ulang gempa 10.000 tahun

Gambar 13 hingga 14 menunjukkan hasil deagregasi untuk periode ulang gempa 2500 dan 10.000 tahun. Pembacaan hasil degregasi dilihat pada persebaran warna, dimana warna merah mempunyai kemungkinan kejadian paling besar, Hasil deagregasi bendugan untuk gempa kala ulang 2500 tahun adalah magnitude dengan range 6,87 hingga 7,13 Mw dan jarak 33 hingga $67 \mathrm{~km}$. Hasil deagregasi bendugan untuk gempa kala ulang 10.000 tahun adalah magnitude dengan range 6,87 hingga 7,13 Mw dan jarak 0 hingga $33 \mathrm{~km}$. Rekapitulasi hasil deagregasi untuk semua periode pengembalian disajikan pada Tabel 4 di bawah ini.

Tabel 4 Rekapitulasi Hasil Deagregasi

\begin{tabular}{ccc}
\hline \multirow{2}{*}{ Periode Ulang } & \multicolumn{2}{c}{ Hasil Deagregasi } \\
\cline { 2 - 3 } & Magnitude $\left(\boldsymbol{M}_{\mathbf{w}}\right)$ & Jarak $(\mathbf{k m})$ \\
\hline 500 tahun & $5,53-5,80$ & $0-33$ \\
\hline 2.500 tahun & $6,87-7,13$ & $33-67$ \\
\hline 10.000 tahun & $6,87-7,13$ & $0-33$ \\
\hline
\end{tabular}

\section{Hasil Pemilihan Ground Motion}

Pemilihan ground motion diambil sesuai dengan besarnya dan jarak dari hasil deaggregasi (Tabel 5). Pemilihan ground motion didapatkan dari website Pacific Gempa Engineering Research (PEER). Gambar 15 hingga 17 menunjukkan hasil pemilihan ground motion untuk periode ulang 500, 2500, dan10000-tahun secara berturut-turut sebagai berikut.

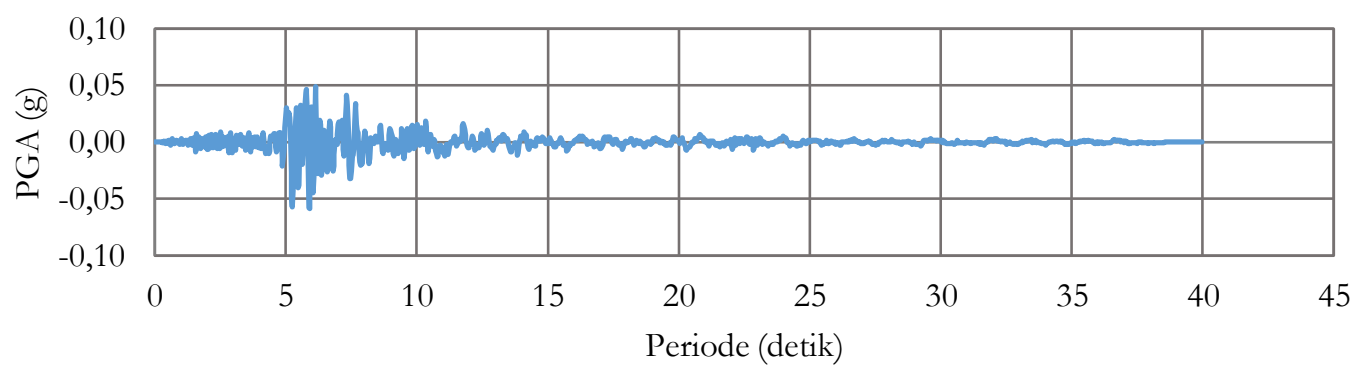

Gambar 15 Akselelogram Gempa Livermore pada tahun 1980 


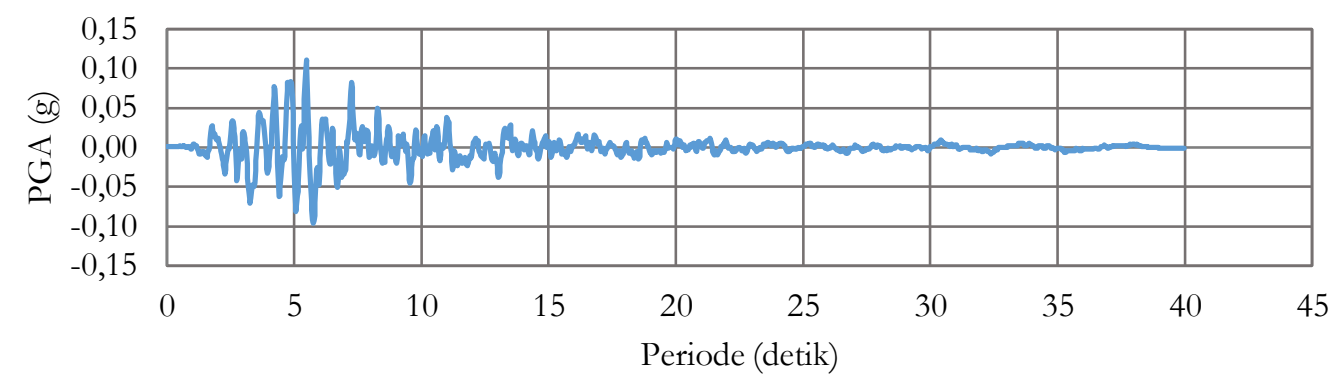

Gambar 16 Akselelogram Gempa Loma Prieta pada tahun 1989

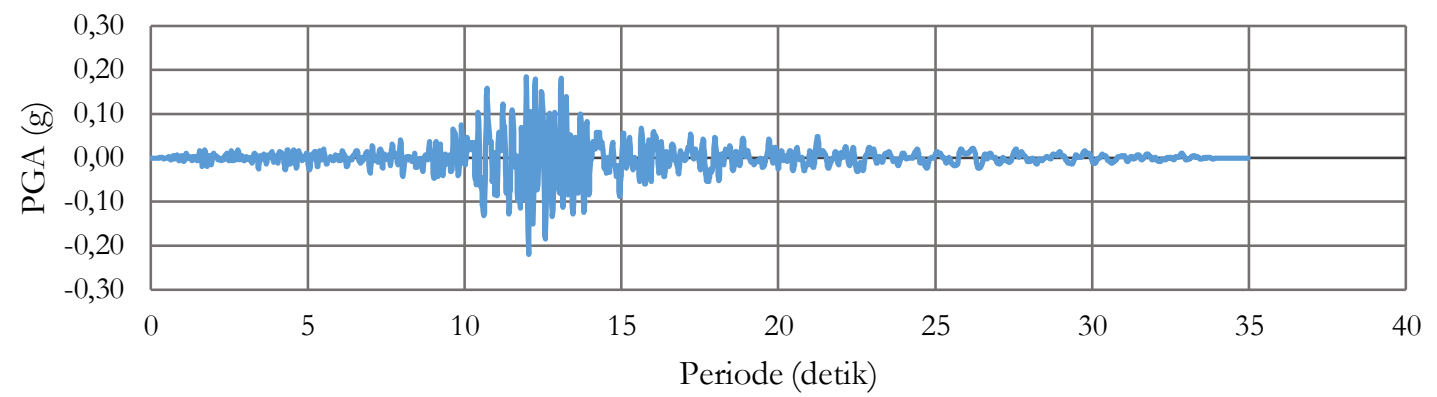

Gambar 17 Akselelogram Gempa Irpinia, Italia pada tahun 1980

\section{SIMPULAN}

Berdasarkan penelitian ini, disimpulkan bahwa:

1. Percepatan tanah maksimum pada Bendungan Wadaslintang adalah $0,22 \mathrm{~g}$ untuk periode ulang 500 tahun, 0,35 g untuk periode ulang 2500-tahun, dan 0,52 g untuk periode ulang 10000-tahun.

2. Berdasarkan hasil deaggregation, kontribusi $\mathrm{M}$ dan $\mathrm{R}$ yang paling berpengaruh dari gempa adalah gempa dengan magnitude 6,87 sampai 7,13 (Mw) yang terletak antara 0 sampai $33 \mathrm{~km}$ dari titik bendungan.

3. Hasil pemilihan ground motion dari beberapa kejadian gempa di dunia, didapatkan akselelogram gempa untuk periode ulang 500, 2.500 dan 10.000 tahun adalah gempa Livermore (1980), Loma Prieta (1989) dan, Irpinia (1980) secara berturut-turut.

\section{REKOMENDASI}

1. Membandingankan hazard metode PSHA dengan software yang berbeda untuk mengetahui keakuratan hasil analisis.

2. Melakukan perhitungan resiko gempa dengan metode Deterministic Seismic Hazard Analysis (DSHA) untuk pembanding hasil metode analisis PSHA.

\section{REFERENSI}

ANSS, http://www.quake.geo.berkeley.edu/anss/catalog-search.html. Accessed on March, 2018

Cornell, C.A., Engineering Seismic Risk Analysis, Bulletin of the Seismological Society of America, Vol. 58 (1968)

Gardner, J.K., and Knopoff L., 1974. Is the sequence of gempas in southern California, with aftershocks removed, Poissonian? Bulletin of the Seismological Society of America, 64, 1363-1367.

Gutternberg, B. and Ritcher, C. Frequency of Gempas in California. Bull. Seism. Soc. Am, 34:185-188 (1944)

Irsyam, M., Ringkasan Hasil Studi Tim Revisi Peta Gempa Indonesia 2010 (2010)

ISC, http://www.isc.ac.uk/iscbulletin/search/catalogue/. Accessed on March, 2018

McGuire, R.K, Deterministic vs Probabilistic Gempa Hazards and Risk, Risk Engineering Inc, Publication Paper (2001)

Merz, H.A and Cornell, C.A, Aftershock in Engineering Seismic Risk Analysis. Report R73-25. Massachusetts: Department of Civil Engineering, MIT. Cambridge (1973)

Reiter, L. (1990). Gempa Hazard Analysis-Issues and Insights. New York: Columbia University Press. 
Stepp. J. C. 1973. Analysis of the Completeness of the Gempa Hazard Sample in the Puget Sound Area. NOAA Technical Report, ERL 267-ESL, 30, Boulder, CO

Tim Pusat Studi Gempa Nasional, Peta Sumber dan Bahaya Gempa Indoensia Tahun 2017, Kementrian Umum dan Perumahan Rakyat, Jakarta, 2017.

USGS, https://gempa.usgs.gov/gempas/search/. Accessed on March, 2018

Wiemer, S., 2001. A software package to analyze seismicity: ZMAP. Seismological Research Letters, 72 (2), $373-$ 382. 